Review article

\title{
MYCOTOXINS - CLIMATE IMPACT AND STEPS TO PREVENTION BASED ON PREDICTION
}

\author{
NEŠIĆ Ksenija*
}

Scientific Institute of Veterinary Medicine of Serbia, Autoput 3, 11070 Belgrade, Serbia

(Received 03 February, Accepted 20 February 2018).

\begin{abstract}
Although mycotoxins occur worldwide and represent a global public health threat, their prevalence and quantities in food and feed may vary due to geographic and climatic differences. Also, in accordance with climate change, outside temperatures that are anticipated to rise and rainfall patterns modify the usual mycotoxicological scheme transforms and unexpectedly extreme events happen in practice more often. Such weather conditions increase fungal occurrence and mycotoxin concentrations in crops. Consequently, the risk to human and animal health grows, and strategies to alleviate adverse effects become more complex. This also elevates economic losses. Therefore, the task of mycotoxin prediction has been put in front of the multidisciplinary scientific community recently, and a targeted prevention has become more important. This paper is a review of the latest achievements in this field prepared with the aim to summarize and integrate available data.
\end{abstract}

Key words: climate changes, food safety, fungal toxins, predictive modeling

\section{INTRODUCTION}

Mycotoxins are produced as secondary metabolites of different types of fungus, belonging primarily to genera Aspergillus, Penicillium and Fusarium. They enter the food chain through contaminated food and feed crops, mainly cereals, which become infested prior to and during harvest, or during (improper) storage. Under favorable environmental conditions, when temperature and moisture are suitable, fungi proliferate and may synthesize toxins. Toxigenic molds are known to produce one or more secondary metabolites, but not all molds are toxigenic, nor are all of their secondary metabolites toxic [1]. Although several hundreds of fungi types have been identified and reported, only a few are of practical significance. Those are aflatoxins (AF), ochratoxins (OT), fumonisins, patulin, zearalenone (ZEA), and trichothecenes including deoxynivalenol (DON) and T-2/HT-2 toxin.

In addition to diseases caused by molds called mycoses [2], the diseases induced by their secondary metabolites are mycotoxicoses. Consumption of a mycotoxin-contaminated

*Corresponding author: e-mail: ksenija_n@yahoo.com 
diet may induce acute and long-term chronic effects. Generally, the influence can be teratogenic, carcinogenic and/or estrogenic or immunosuppressive. However, the major problem associated with mycotoxin contamination of the animal feed supply chain is reduced animal productivity. Direct effects include reduced feed intake, feed refusal, poor feed conversion, diminished body weight gain, increased disease incidence and reduced reproductive capacities that all lead to economic losses [3]. Although mycotoxins mainly affect grains, meat, milk and eggs can be adversely affected, so consumption of such products of animal origin has direct consequences to humans. It is also known that inhalation or dermal exposure should not be neglected [4].

Mycotoxin contamination is considered an unavoidable naturally occurring problem, even where good agricultural, storage and processing practices are implemented, representing a great challenge to food safety. Many of them are impossible to eliminate during food treatment because of their stability against heat, physical and chemical influence [5]. These contaminants are the main hazard mentioned in EU border rejection notifications according to Rapid Alert System for Food and Feed (RASFF), with aflatoxins as the most common [6]. Many national and international public health and governmental authorities, such as the World Health Organization (WHO), Food Agriculture Organization (FAO), the European Food Safety Authority (EFSA) and the US Food and Drug Administration (FDA) pay serious attention to the presence of mycotoxins in food and feed and have adopted strict regulatory guidelines for maximum permitted levels, as shown in Table 1 [5].

Table 1. Maximum permitted levels of mycotoxins in food: EU vs. USA

\begin{tabular}{|c|c|c|c|}
\hline Mycotoxin & Food matrix & $\begin{array}{c}\text { EU (EC } \\
\text { 1881/2006) [7] } \\
{[\mu \mathrm{g} / \mathrm{kg}]}\end{array}$ & $\begin{array}{l}\text { US FDA }[8] \\
{[\mu \mathrm{g} / \mathrm{kg}]}\end{array}$ \\
\hline Aflatoxins B1, B2, G1, G2 & $\begin{array}{l}\text { Cereals, cereal products, rice, nuts, } \backslash \\
\text { dried fruits, spices }\end{array}$ & $\begin{array}{l}2-12 \text { for } \mathrm{B} 1 \\
4-15 \text { for total }\end{array}$ & 20 for total \\
\hline Aflatoxin M1 & Milk, milk products & $\begin{array}{l}0.05 \text { in milk } \\
0.025 \text { in infant } \\
\text { formulae and } \\
\text { infant milk }\end{array}$ & 0.5 \\
\hline Ochratoxin A & $\begin{array}{l}\text { Cereals, dried vine fruit, wine, grapes, } \\
\text { coffee, cocoa, spices }\end{array}$ & $2-80$ & - \\
\hline Fumonisins B1,B2, B3 & Maize, maize, products & $200-4000$ & $2000-4000$ \\
\hline Patulin & $\begin{array}{l}\text { Fruit and apple juices, apple products, } \\
\text { infant foods }\end{array}$ & $10-50$ & 50 \\
\hline Zearalenone & $\begin{array}{l}\text { Cereals, cereal products, maize, maize oil, } \\
\text { infant foods }\end{array}$ & $20-400$ & - \\
\hline Deoxynivalenol & Cereals, cereal products, infant foods & $200-1750$ & 1000 \\
\hline
\end{tabular}

Aside from health risks, important economic and trade implications arise from the mycotoxin contamination of food and feed. That includes loss of crop production, 
disposal of contaminated food and feed, reduced livestock production, increased human and animal health care costs, analytical and regulatory costs and investment in research [9]. Therefore, it is of extreme importance to find a way to predict mycotoxin occurrence and thus to implement targeted prevention strategies. This task has been put in front of the multidisciplinary scientific community with the aim to develop some predictive models, which are expected to be useful for various stakeholders as end-users, from farmers to food and feed industry and authorities.

\section{CLIMATE CHANGE AND MYCOTOXINS}

Exposure to mycotoxins is present worldwide, even though there are geographic and climatic differences in their production and occurrence. Fungi are a normal part of the microflora of field and stored crops, but the production of mycotoxins depends upon the type of fungi, agronomic practices, the composition of the commodity and the conditions of harvesting, handling and storage. The amount of produced toxin will depend on physical factors (water activity $a_{w)}$ moisture, relative air humidity, temperature and mechanical damage of grains), chemical factors (carbon dioxide, oxygen, composition of substrate, pesticide and fungicides) and biological factors (plant variety, stress, insects, spore load) [10]. Two most important factors which affect the life cycle of all microorganisms, including mycotoxigenic molds, are water availability and temperature. A summary of the major production data and their physiological effects is given in Table 2 [11].

Table 2. Mycotoxins, associated fungi, optimal production conditions and toxical effects

\begin{tabular}{|c|c|c|c|c|}
\hline Mycotoxin & Fungi & $\begin{array}{c}\text { Temp } \\
{\left[{ }^{0} \mathrm{C}\right]}\end{array}$ & $\begin{array}{l}\text { Water activity } \\
{\left[\mathrm{a}_{\mathrm{w}}\right]}\end{array}$ & Toxicity \\
\hline Aflatoxins & $\begin{array}{l}\text { Aspergillus flavus, } \\
\text { A. parasiticus }\end{array}$ & 33 & 0.99 & $\begin{array}{l}\text { carcinogenic, acute hepatotoxic, } \\
\text { immuno suppression }\end{array}$ \\
\hline Ochratoxins & $\begin{array}{l}\text { Aspergillus ochraceus, } \\
\text { A. carbonarius, } \\
\text { Penicillium verrucosum }\end{array}$ & $15-30$ & $0.85-0.98$ & $\begin{array}{l}\text { carcinogenic, nephrotoxic, } \\
\text { hepatotoxic, teratogenic }\end{array}$ \\
\hline Fumonisins & $\begin{array}{l}\text { Fusarium verticillioides, } \\
\text { F. proliferatum }\end{array}$ & $10-30$ & 0.93 & carcinogenic, hepatotoxic \\
\hline Patulin & Penicillium expansum & $24^{\circ} \mathrm{C}$ & 0.99 & $\begin{array}{l}\text { acutely toxic, genotoxic, } \\
\text { teratogenic, immunotoxic }\end{array}$ \\
\hline Zearalenone & $\begin{array}{l}\text { Fusarium graminearum, } \\
\text { F. culmorum }\end{array}$ & $25-30$ & 0.98 & estrogenic activity \\
\hline Deoxynivalenol & $\begin{array}{l}\text { Fusarium graminearum, } \\
\text { F. culmorum, } \\
\text { F. sporotrichioides, } \\
\text { F. roseum, F. tricinctum, } \\
\text { F. acuminatum }\end{array}$ & $15-25$ & $0.97-0.99$ & $\begin{array}{l}\text { gastrointestinal hemorrhaging, } \\
\text { immunodepressants }\end{array}$ \\
\hline
\end{tabular}


However, it is already evident that the climate changes ahead will affect mycotoxins in the food. According to the intergovernmental panel on climate change report [12] concentrations of methane, carbon dioxide, nitrous oxide and chloro-fluorocarbons in the atmosphere are increasing, resulting in environmental warming, greater precipitation, or drought. Extreme climatic events are already present and can be seen more and more frequently. Circumstances of temperature and rainfall changing may threaten food security [13-16] and will have a negative impact especially in developing countries.

According to the EU green paper, in the recent years the statistical and scientific evidence has shown that the climate is being disrupted by the build-up of greenhouse gases as a result of our pattern of development [17]. The situation in Europe will vary regionally and would be either detrimental or advantageous. This might increase the risk of migration of pathogens as a response to warmer, drought-like climatic conditions. Also, plant physiology could be affected, as well as stomatal patterns on leaf surfaces, which would impact transpiration and photosynthetic capacity and will enable invasion by pests and pathogens. There are findings that elevated $\mathrm{CO}_{2}$ and temperature may modify the mycoflora of cereals during ripening, so that such conditions may have an effect on the colonization by mycotoxigenic fungal genera which contaminate food and raw materials [18].

Specific extreme weather conditions have been recently recorded in Europe and findings of aflatoxins in Northern Italy [19] and Serbia [20], as well as the isolation of A. flavus in Hungary [21], have been noted. According to the report of the Republic Hydro -Meteorological Service of Serbia [22], production year 2012 was characterized by pronounced climatic changes. Prolonged periods of extremely high air temperatures during June, July and August, as well as a precipitation deficit, resulted in severe and extreme droughts. Substantial damage and losses in agricultural crop production were manifested also by contamination with Aspergillus fungi and high concentration of their metabolites aflatoxins in corn, and consequently in milk [13]. The opposite situation has been recorded in 2014, in accordance with the weather conditions at that time, with a lot of rain and moisture [23], when a large percentage of corn and wheat samples were contaminated by mycotoxins zearalenone and deoxynivalenol produced by Fusarium fungi [15].

Anticipated weather conditions in Europe with high environment temperature and drought will reduce water availability and crop productivity in the south. Warming in the range of about $3^{\circ} \mathrm{C}$ will result in changes in species assemblages. Southern Europe will probably experience a decrease of spring-sown crops (e.g. corn, sunflowers and soybean) whose cultivation will become more convenient in Northern areas. Corn production is expected to increase by $30-50 \%$ in Northern European regions, but to decrease strongly in the south of Europe. The mycotoxin problem may "follow the crop" [10]. 
In Southern and South-Eastern Europe, an increase in the order of $4-5^{\circ} \mathrm{C}$ is projected and water availability will be reduced, particularly in summer. This combined effect could induce a decrease in agricultural yields (in the range of $10-30 \%$ in many regions), drought, heat waves, soil and ecosystem degradation and desertification. Drought and heat may increase aflatoxin levels in grains generally [17]. Western and Atlantic Europe countries will experience an increase of approximately $2.5-3.5^{\circ} \mathrm{C}\left(2-3^{\circ} \mathrm{C}\right.$ for UK and Irish Republic) with dryer and hotter summers. Due to higher volumes and intensities of precipitation, strong storms and floods are projected to be more frequent particularly in winter. Proper drying down of crops may be impaired causing increased mycotoxins in stored products.

For areas of central Europe, an increase of $3-4^{\circ} \mathrm{C}\left(4-4.5^{\circ} \mathrm{C}\right.$ for Central Europe and Black Sea Regions) is projected and precipitation may magnify in winter and reduce in summer, with an enlarged risk of floods. Agriculture is expected to be affected by soil erosion, loss of soil organic matter, migration of pests and diseases, summer drought and high temperature. In northern Europe and Baltic States, temperature increase in the order of $3-4.5^{\circ} \mathrm{C}$ and an increase of yearly precipitation up to $40 \%$ are projected with risks for floods. The overall results of climate change would be an increase in crop yield $\left(10-30 \%\right.$ for warming in the range $\left.1-3^{\circ} \mathrm{C}\right)$ and novel crops may be cultivated [17].

As a result of the rise of temperature, more insect pests will occur [12], which are an important factor in the contamination with mycotoxigenic fungi. More insects may also increase the number of insect-feeding birds, possibly resulting in more damage to crops caused by them, which will contribute to higher synthesis of mycotoxins. Changes in crop phenology, such as timing of flowering and maturation of cereals, are also foreseen. Crop geographic distribution and crop production, as well as the mycoflora of crops, are expected to be strongly affected by climate change $[24,25]$.

\section{PREDICTING MODELS}

Based on recent experience with climate and near-future predictions of its modifications, the first priority over this decade is the collation of accurate mycotoxin contamination and weather data. The final goal is the development of models to forecast the effects of climate change on mycotoxins, with the aim to provide the necessary foresight for strategic adaptation to climate change and implementation of adequate prevention systems [10].

Modeling studies provide increasingly realistic scenarios for the influence of changes in the magnitude and variability of precipitation, temperature, etc. on mycotoxin contamination. Battilani et al. [26] emphasize that probably large regions of Europe will experience some non-compliance with EU legislative limits for food and feed. It is possible that similar impacts could be felt in other important food production areas 
in Asia, North and South America. This will have both food security and economic effects, even if new levels may still be below regulatory limits [27].

Predicting models represent a dynamic simulation by numerical integration of component processes, supported by computers and based on existing knowledge, as defined by Kumar [28] regarding crop modeling. This concept is perfectly applicable to modeling mycotoxins in crops when aimed to describe how mycotoxin producing moulds respond to key drivers, mainly weather variables. Although modeling that combines data on climate, pathogen and host, provides great support by giving estimates of mycotoxin risk and prediction of the possibility of mycotoxicoses, as a research area it is still in the beginning stage and only few studies could be found in literature [29].

Van der Fels-Klerx et al. [30] reviewed three promising quantitative modeling approaches for impacts of climate change on mycotoxins focused on Europe. One study treated deoxynivalenol (DON) concentrations in wheat produced in north west Europe [31, 32], while the other study analyzed aflatoxin $\left(\mathrm{AFB}_{1}\right)$ contamination of corn, wheat and rice in whole Europe [24,33] and the third one was a case study on Alternaria molds and their mycotoxins in tomatoes [34]. Studies applied models of different disciplines including climate projection, crop phenology and fungal/ mycotoxin prediction.

As inputs for the DON prediction model in northwestern Europe (Norway, Sweden, Finland and The Netherlands), within the EMTOX project, a climate model projection for the future period 2031-2050 was used, as well as crop and fungi phenology. It included DON concentrations in mature wheat, agronomical practices and local weather. Multiple regression analyses were conducted and the best set of explanatory variables, mainly including weather factors, was selected. The final model included the following variables: flowering date, length of time between flowering and harvest, wheat resistance to Fusarium infection and several climatic variables related to relative humidity, temperature and rainfall during critical stages of wheat cultivation [35].

In this empiric study, the climate data covered 851 grids of $50 \times 50 \mathrm{~km}$ in total with 50 simulations per grid. Crop phenology and DON prediction models were run for each of spring wheat and winter wheat separately. Contamination of winter wheat with DON was generally expected to be increased in most of the study area with a factor of two and up to a factor of four in some grids. For spring wheat, even more severe impacts were seen. However, variation between runs and between regions was large, and in some grids a decrease in DON levels was expected [30].

A mechanistic modeling approach was implemented in the AFLA project to predict future aflatoxin contamination of maize cultivated in Europe [24,33]. It considered three selected climate change scenarios: current, $+2{ }^{\circ} \mathrm{C}$, and $+5^{\circ} \mathrm{C}$. Meteorological data for temperature, relative humidity and rainfall were used in 100 runs, from the period 2000-2100, on a $50 \times 50 \mathrm{~km}$ grid in Europe. Using the weather facts a European database was used to estimate the shifts in maize flowering and harvesting in the three 
different climate scenarios. Results showed a reduction in the length of the cultivation season, and earlier flowering and harvest dates. This would lead to an enlargement of the area in Europe suitable for maize cultivation towards the Northern area. Weather data and estimated shifts in maize phenology were then inputs for the AFLA-maize model. An expected increase of aflatoxin contamination of maize, mainly in the $+2{ }^{\circ} \mathrm{C}$ scenario was shown. In this case, a particularly higher AFB contamination was seen in the southern European countries, like central and southern Spain, center and south of Italy and the Balkans. In the $+5^{\circ} \mathrm{C}$ scenario, the area in Europe for which maize contamination was predicted was much higher than in the $+2^{\circ} \mathrm{C}$. However, estimated $\mathrm{AFB}_{1}$ contaminations were lower than in the $+2{ }^{\circ} \mathrm{C}$.

Van de Perre et al. [34] presented their study for the quantification of the effect of increasing temperature on mold growth and mycotoxin production on tomato using different climate scenario analysis for the current, near (2031-2050) and far future (2081-2100) in Spain and Poland. The results showed that the impacts are region specific. For Spain, the temperatures were projected too high $\left(18.2-38.2^{\circ} \mathrm{C}\right)$ for Alternaria spp. to grow, thus the diameter of the mold was calculated lower in the far future compared with the current time frame. On the other hand, the projected temperatures for Poland become closer to the optimal temperature $\left(14.2-28.4^{\circ} \mathrm{C}\right)$ for Alternaria spp. to grow. According to this study, the situation in Poland in the far future (2081-2100) is projected similar as the situation in Spain at the present time (19812000).

As noted by Van der Fels-Klerx et al. [30] the available predictive models for mycotoxins are validated in only few countries and climate change impact studies for mycotoxins focus on some selected mycotoxin-crop combinations only. Based on these findings, predictive modeling seems to be a very promising approach, but more combinations of mycotoxins-crops are needed to be taken into account with the aim to better assist mycotoxin management during crop cultivation in Europe, and to mitigate the expected climate change impacts on mycotoxins.

\section{PREVENTION}

As already mentioned, contamination of food and feed with mycotoxins is the result of the interaction between the fungi producing the toxin, the susceptible substrate and the environment. There is no region of the world that can methodically avoid this problem, but there are ways to alleviate it. Application of good agricultural practices during cultivation, good manufacturing practices during handling, storage, processing and distribution, as well as hazard analysis and critical control point (HACCP) procedures will ensure that fungal infection and mycotoxin formation are as low as possible given the circumstances [36]. Emphasis should be placed on the fact that the planting, preharvest and postharvest strategies for a particular crop will depend on the climatic conditions of that particular year, taking into account the local crops and traditional production conditions for that particular country or region 
[37]. An example of a comprehensive approach to management of mycotoxins has been given by Rossi et al. [38] who conducted a long-term project that implemented a model included in a web-based decision support system (DSS) named granoduro. net. The DSS provided plot-specific and up-to-date decision supports about weather, fertilization, crop growth, weed control and disease and mycotoxin risk. Together with good agricultural practices it was applied for 2 years in 25 pilot farms across Italy. DSS use reduced external inputs (i.e. seeds, fungicides and fertilizers) and costs, maintained or increased crop yield and quality and kept mycotoxin contamination below the legal limit. Thus, the DSS significantly increased the farmers' income and reduced emission of greenhouse gasses. Therefore, strategies to fight mycotoxins in the future should be more based on climate predictions and use of mycotoxin predictive models.

Harmful effects of mycotoxin contamination in the food supply chain can be reduced by preventing contamination, removing contaminated material from the food commodity, mitigating mycotoxin content in food and feed and treating exposed individuals [39]. Current strategies to combat mycotoxins can be divided in preharvest treatments to reduce or inhibit production of the toxins in the field and postharvest remediation of contaminated commodities. The priority therefore remains prevention of toxin accumulation directly on the field (preharvest) or thereafter (transport and storage) [40]. A variety of agricultural practices are the first recommended, e.g. crop rotation, soil tillage, irrigation, weed control, growing crop varieties that have proved to be more resistant to fungi and insect injuries. Chemical and biological control of plant diseases and insect control are also available to minimize mycotoxin production in the field. Use of compatible fungicides at the right time and in the appropriate way, or biological control with microbial antagonists or competitors, can be integrated in contamination control strategies by spraying agents on plants to eradicate or limit the growth of toxin producers. Early harvest followed by drying of the grains can help avoid increased mycotoxin contamination also. During harvest, it is of utmost importance to use adequate harvesting equipment that is correctly adjusted to avoid damage of the kernel, since damaged kernels are predisposed to infection during storage. Proper preharvest conditions are crucial to prevent fungal growth and mycotoxin accumulation in the harvested commodities $[3,39]$.

However, preharvest measures do not guarantee the absence of mycotoxins in the food or feed and these preventive strategies are not always enough to eliminate mycotoxins completely. Damaged and high moisture crop parts should be removed from the harvest as they pose a great risk of contamination. As avoidance of mycotoxin contamination depends primarily on moisture control, the kernel must be desiccated as soon as possible and optimal humidity maintained. The final safe moisture content depends on the crop and climatic conditions under which the commodity is stored [37]. During long-term storage, the kernel is exposed to oscillations in temperature and humidity and pests of different species. Insect and rodent control is important not only because their activity in stored products creates favorable microclimates for fungal growth, but also because they damage kernels and, therefore, predisposes them 
to fungal manifestation. Therefore, good storage practices include good cleaning and hygiene, moisture of grains and humidity control, temperature control, combined cooling and drying operations associated with ventilation systems are necessary, rodent and insects control, chemical preservatives and antifungal agents (acids, mould inhibitors).

Because mycotoxin contamination is often unavoidable, there is a demand for practical and economical inactivation and detoxification methods, with irreversible effectiveness and ability to modify mycotoxins together with their parent compounds, which are non-harmful itself, while the food and feed should retain its nutritive value and remain palatable $[41,42]$. There are many physical and chemical methods of detoxification available, based on washing procedures, radiation, ultrasound, extraction with organic solvents, use of calcium hydroxide monomethylamine, sodium bisulfite, moist and dry ozone, chlorine gas, hydrogen peroxide, ascorbic acid, hydrochloric acid, sulfur dioxide gas, formaldehyde, ammonia and ammonium hydroxide. Their implementation needs special equipment and additional time, leading to an increase in costs. The efficiency of these methods highly depends on the level of contamination and the distribution of mycotoxins throughout the grain. The obtained results are uncertain; they often destroy essential nutrients and represent a potential risk to workers. Thus, usually there is no practical application of these methods [37].

Searching for other solutions to combat the mycotoxin hazard, deactivation techniques directly in the gastrointestinal tract were investigated. This possibility includes usage of various feed additives, which either adsorb mycotoxins on their surface, or they provide enzyme degradation of mycotoxins. Adsorbing materials are those that bind mycotoxins in the gastrointestinal tract to form a stable complex which will not dissociate as it passes through the animal. On the other hand, some materials can transform mycotoxins as a way to reduce exposure. Microorganisms, such as bacteria and fungi, can contain enzymes that degrade mycotoxins into non-toxic compounds $[43,44]$.

Adsorbing agents primarily include natural clay products and yeasts [45]. They decrease the bioavailability of mycotoxins thus causing a reduction of mycotoxin uptake and decreased distribution to the blood and target organs. Adsorbing agents are also called binding agents, adsorbents, binders, etc. This group comprises of: activated carbons, yeast cell walls derived from the Saccharomyces cerevisiae, micronized fibers obtained from different plant materials such as cereals (wheat, barley, oat), pea hulls, apple, bamboo, etc.; Lactic acid bacteria such as Lactobacillus rhamnosus strain GG and Lactobacillus rhamnosus strain LC-705; Polymers (cholestyramine and polyvinylpyrrolidone) and the most known group of aluminosilicates with two important subclasses: the phyllosilicates and the tectosilicates. Phyllosilicate subclass include bentonites, montmorillonites, smectites, kaolinites, illites. The tectosilicates include zeolites.

Biotransforming agents include bacteria, yeasts, fungi and enzymes that have the ability to specifically degrade mycotoxin molecules into non-toxic metabolites [45]. 
For aflatoxins interesting results have been obtained by Flavobacterium aurantiacum application. This soil bacterium was shown to significantly remove aflatoxins from several substrates, including animal feeds, and was found safe for chickens. So far, Trichosporon mycotoxinivorans is the only microorganism that shows the potential to degrade OTA and meets the prerequisites for use as animal feed additive. Although the efficacy of T. mycotoxinivorans in degrading ZEA to a metabolite needs to be assayed by animal trials, it shows a good potential to be used as an animal feed additive. There are many publications on biological transformation of trichothecenes, but only two microorganisms (Eubacterium: BBSH 797 and LS100) show the potential to be used for biodetoxification of trichothecene contaminated animal feeds.

There are certain combinations between the two or more basic groups of feed additives that form the category of multicomponent adsorbents. In the trial of Nesic et al. [46] a multicomponent mycotoxin adsorbent was used. Adsorption capacities were upgraded by the addition of enzymes (de-epoxydase and lactonase) in order to cope with the more non-polar mycotoxins, like T-2 toxin, and showed a success by transforming T-2 toxin into inactive de-epoxy-HT-2 toxin by deacetylation, through the intermediate HT-2 toxin. The results presented by Nedeljković Trailović et al. $[47,48]$ showed that the best results, in broilers exposed to the influence of $2 \mathrm{mg}$ OTA/kg feed and three different adsorbents (mineral adsorbent, yeast-wall derived adsorbent, multicomponent adsorbent) on performance, pathohistological changes in the kidney and on the level of residues of OTA in the liver and breast muscles, were achieved in the groups of broilers which received the multicomponent adsorbent along with OTA.

The efficacy of a feed additive depends on the chemical structure of both the detoxifying agent and the mycotoxin [49]. Moreover, the effects of specific mycotoxins and detoxifying agents differ for each animal species. In poultry, many feed additives showed positive effects in tests on broilers, but less data are available in other bird species. However, Tilley et al. [50] recently used three mycotoxin adsorbents in turkey diet to investigate their influence on aflatoxin (AF), deoxynivalenol (DON) and zearalenone (ZEA) and published positive results to some degree, especially with respect to feed conversion of animals in the experiment. In pigs, the mineral adsorbing agents are effective in detoxifying aflatoxins, but seem to have no beneficial effect on trichothecenes. Nevertheless, some prebiotics and probiotics are effective in detoxifying trichothecenes. Ruminants are more resistant to mycotoxins than other species, but a special attention should still be paid to the possible transfer of mycotoxins, in particular aflatoxins, into the milk. The detoxifying agents used in ruminants are mainly adsorbing agents and most of them are inorganic. In general, adsorbing and biotransforming agents have been effective in detoxifying aflatoxins, while mineral adsorbing agents were less effective against other groups of mycotoxins. Very little data is available on the effect of detoxifying agents tested on diets with mycotoxins present below the regulatory level [45]. 


\section{CONCLUSIONS}

Profound studies to improve information and support the best mycotoxin prevention strategies for the comprehensive "field to table" combating program against mycotoxins are still needed. Successful approach should involve Good Agricultural Practice, Good Manufacturing Practice, Good Storage Practice, HACCP principles and Good Laboratory Practice for mycotoxin monitoring, as well as development of models to forecast the effects of weather conditions on mycotoxins for strategic adaptation to climate change. The number of predictive models for mycotoxin contamination in crops is still low and it needs to be enlarged. Future risk assessment should involve a wider concept, as new mycotoxins could arise from new fungus and plant associations, making the occurrence of new mycotoxins or mycotoxins not yet considered as harmful. Such investigations, including climate projection, crop phenology and fungal/mycotoxin prediction, would be necessary and highly beneficial for different stakeholders. Farmers would use predictions to underpin decision making on the application of prevention measures, using the most accurate predictions available at that critical growing stage. The feed and food industry, including collectors, millers and processors, may use it to focus their inspections and decide on the buying, routing and processing of batches. Food safety authorities are expected to improve inspection efficiency based on mycotoxin predictions in constructing their yearly monitoring plan. Therefore, an interdisciplinary principle is the key to make predictive models a true support to start the downward trend in mycotoxin contamination of food and feed. Usually, the road motive is the economic effect that is achieved in this way, but above all, human and animal health is priceless.

\section{Authors' contributions}

NK has design the paper, selected reference for the presentation and wrote the manuscript. NK takes responsibilities for all aspects of the work and accuracy of the quoted data in the manuscript.

\section{Declaration of conflicting interests}

The author(s) declared no potential conflicts of interest with respect to the research, authorship, and/or publication of this article.

\section{REFERENCES}

1. Brase S, Encinas A, Keck J, Nising CF: Chemistry and biology of mycotoxins and related fungal metabolites. Chem Rev 2009, 109:3903-4399. 
2. Timurkaan N, Eroksuz H, Ongor H, Cevik A, Karabulut B, Toraman Z A,Eroksuz Y, Incili C A: Concurrent occurrence of lower respiratory aspergillosis and pneumoconiosis in a turkey flock. Acta Veterinaria-Beograd 2017, 67 (4), 562-571.

3. Nesic K, Ivanovic S, Nesic V: Fusarial Toxins - Secondary Metabolites of Fusarium Fungi. Rev Environ Contam Toxicol 2014, 228: 101-120.

4. Ostry V, Malir F, Toman J, Grosse Y: Mycotoxins as human carcinogens-the IARC Monographs classification. Mycotoxin Res 2017, 33:65-73.

5. Alshannaq A and Yu JH: Occurrence, Toxicity and Analysis of Major Mycotoxins in Food. Int J Environ Res Public Health 2017, 14: 632-652.

6. Marin S, Ramos AJ, Cano-Sancho G, Sanchis V: Mycotoxins: Occurrence, toxicology, and exposure assessment. Food Chem Toxicol 2013, 60: 218-237.

7. EC 1881/2006- Commission Regulation (EC) No 1881/2006 of 19 December 2006 Setting Maximum Levels for Certain Contaminants in Foodstuffs. Off J Eur Union. 2006. 5-24.

8. US FDA - Chemical Contaminants, Metals, Natural Toxins \& Pesticides Guidance Documents \& Regulations, 2000-2010. https://www.fda.gov/Food/Guidance Regulation/ Guidance Documents Regulatory Information/Chemical Contaminants Metals Natural Toxins Pesticides/default.htm

9. Pinotti L, Ottoboni M, Giromini C, Dell'Orto V, Cheli F: Mycotoxin Contamination in the EU Feed Supply Chain: A Focus on Cereal Byproducts. Toxins 2016, 8: 45-69.

10. Nesic K, Milicevic D, Nesic V, Ivanovic S: Mycotoxins as one of the foodborne risks most susceptible to climatic change. Procedia Food Sci 2015a, 5:207-210.

11. Lee HJ and Ryu D: Worldwide Occurrence of Mycotoxins in Cereals and Cereal-Derived Food Products: Public Health Perspectives of Their Co-occurrence. J Agric Food Chem 2017, 65: 7034-7051.

12. IPCC. Intergovernmental panel on climate change repor t. 52 pp. Climate Change: Synthesis Report 2007, 1-103. https://www.ipcc.ch/pdf/assessment-report/ar4/syr/ar4_syr_full_ report.pdf

13. Jaksic S, Zivkov-Balos M, Prica N, Masic Z, Nesic K, Jajic I, Abramovic B: The influence of climatic factors in Serbia on mycotoxin production. Proc I Int Symp Vet Med (ISVM2015) 2015, 166-172.

14. Miraglia M, Marvin HJP, Kleter GA, Battilani P, Brera C, Coni E, Cubadda F, Croci L, De Santis B, Dekkers S, Filippi L, Hutjes RWA, Noordam MY, Pisante M, Piva G, Prandini A, Toti L, van den Born GJ, Vespermann A: Climate change and food safety: An emerging issue with special focus on Europe. Food Chem Toxicol 2009, 47(5):1009-1021.

15. Nesic K, Jaksic S, Zivkov-Balos M, Prunic B. Mycotoxicological assessment of feed in Serbia in 2014 in the light of new legislation. Proc I Int Symp Vet Med (ISVM2015) 2015b, 124-132.

16. Tirado MC, Clarke R, Jaykus LA, McQuatters-Gollop A, Frank JM: Climate change and food safety: A review. Food Res Int 2010, 43(7):1745-1765.

17. EC - European Commission. Adapting to Climate Change in Europe - Options for EU Action. Green Paper from the Commission to the Council, the European Parliament, the European Economic and Social Committee of the Regions. 2007, 1-27. http://eur-lex. europa.eu/legal-content/EN/TXT/PDF/?uri=CELEX:52007DC0354\&from=EN

18. Magan N, Medina A, Aldred D: Possible climate-change effects on mycotoxin contamination of food crops pre- and postharvest. Plant Pathol 2011, 60:150-163. 
19. Giorni P, Battilani P, Magan N. Effect of solute and matric potential on in vitro growth and sporulation of strains from a new population of Aspergillusflavus isolated in Italy. Fungal Ecology 2008; 1(2-3):102-6.

20. Nesic K. Pavlovic N. Current mycotoxicological profile of Serbian feed. Proc Int $57^{\text {th }}$ Meat Ind Conf; 2013, 320-323.

21. Varga J, Koncz Z, Kocsube S, Matrai T, Teren J, Ostry V, SkarkovaJ, RuprichJ, Kubatova A, KozakiewiczZ. Mycobiota of grapes collected in Hungarian and Czech vineyards in 2004. Acta Aliment 2007;36(3):329-341

22. RHMZ: Republic Hydrometeorological Service of Serbia. Agrometeoroloski uslovi u proizvodnoj 2011/2012 godini na teritoriji R.Srbije, 2012.

23. RHMZ: Republic Hydrometeorological Service of Serbia. Agrometeoroloski uslovi u proizvodnoj 2013/2014 godini na teritoriji R.Srbije, 2014.

24. Battilani P, Toscano P, Van der Fels-Klerx HJ, Moretti A, Camardo Leggieri M, Brera C, Rortais A, Goumperis T, Robinson T: Aflatoxin B1 contamination in maize in Europe increases due to climate change. Sci Rep 2016a, 6 http://dx.doi.org/10.1038/srep24328.

25. Vaugham M, Backhouse D, Del Ponte E: Climate change impacts on the ecology of Fusarium graminearum species complex and wheat susceptibility to Fusarium head blight: a review. World Mycotox J 2016, 9(5): 685-700.

26. Battilani P, Stroka J, Magan N: Foreword: mycotoxins in a changing world. World Mycotoxin J 2016b, 9(5): 647-651.

27. Wu F, Mitchell, NJ: How climate change and regulations can affect the economics of mycotoxins. World Mycotoxin J 2016, 9(5): 653-663.

28. Kumar M: Impact of climate change on crop yield and role of model for achieving food security. Environ Monit Assess 2016, 188(8):465.

29. Battilani P: Recent advances in modeling the risk of mycotoxin contamination in crops. Curr Opin Food Sci 2016, 11:10-15.

30. Van der Fels-Klerx HJ, Liu C, Battilani P: Modelling climate change impacts on mycotoxin contamination. World Mycotoxin J 2016, 9(5): 717-726.

31. Van der Fels-Klerx H, Olesen JE, Madsen M, Goedhart P: Climate change increases deoxynivalenol contamination of wheat in north-western Europe. Food Addit Contam Part A 2012a, 29: 1593-1604.

32. Van der Fels-Klerx H, Olesen JE, Naustvoll L-J, Friocourt Y, Mengelers M, Christensen $\mathrm{J}$ : Climate change impacts on natural toxins in food production systems, exemplified by deoxynivalenol in wheat and diarrhetic shellfish toxins. Food Addit Contam Part A 2012b, 29: 1647-1659.

33. Battilani P, Rossi V, Giorni P, Pietri A, Gualla A, van der Fels-Klerx HJ, Booij CJH, Moretti A, Logrieco A, Miglietta F, Toscano P, Miraglia M, De Santis B, Brera C: Scientific report submitted to EFSA: Modelling, predicting and mapping the emergence of aflatoxins in cereals in the EU due to climate change. 2012, 1-172. http://www.elika.eus/datos/ articulos/Archivo_EU792/EFSA\%20Cambio\%20climatico.pdf

34. Van de Perre E, Jacxsens L, Liu C, Devlieghere F, De Meulenaer B: Climate impact on Alternaria moulds and their mycotoxins in fresh produce: the case of the tomato chain. Food Res Int 2015, 68: 41-46.

35. Van der Fels-Klerx H, Goedhart P, Elen O, Börjesson T, Hietaniemi V, Booij C: Modeling deoxynivalenol contamination of wheat in northwestern Europe for climate change assessments. J Food Prot 2012c, 75: 1099-1106. 
36. Codex Alimentarius Commission (CAC): Code of practice for the prevention and reduction of mycotoxin contamination in cereals, including annexes on ochtratoxin $\mathrm{A}$, zearalenone, fumonisins and tricothecences. CAC/RCP 51-2003; Available from: http://www.fao.org/ fao-who-codexalimentarius/en/

37. Awad WA, Ghareeb K, Josef Bohm J, Zentek J: Decontamination and detoxification strategies for the Fusarium mycotoxin deoxynivalenol in animal feed and the effectiveness of microbial biodegradation. Food Addit Contam 2010, 27(4): 510-520.

38. Rossi V, Manstretta V, Ruggeri M: A multicomponent decision support system to manage Fusarium head blight and mycotoxins in durum wheat. World Mycotox J 2015, 8 :629-640.

39. Karlovsky P, Suman M, Berthiller F, De Meester J, Eisenbrand G, Perrin I, Oswald IP, Speijers G, Chiodini A, Recker T, Dussort P: Impact of food processing and detoxification treatments on mycotoxin contamination. Mycotoxin Res 2016, 32:179-205.

40. Choudhari AK, Kumari P: Management of mycotoxin contamination in preharvest and postharvest crops: present status and future prospects. J Phytology 2010, 2:37-52.

41. Milani J, Maleki G: Effects of processing on mycotoxin stability in cereals. J Food Sci and Agric 2014, 94:2372-2375.

42. Patriarca A, Pinto VF: Prevalence of mycotoxins in foods and decontamination. Curr Opin Food Sci 2017, 14:50-60.

43. Chaytor A, Hansen JA, van Heugten E, See MT, Kim SW: Occurrence and Decontamination of Mycotoxins in Swine Feed. Asian-Aust. J. Anim. Sci. 2011, 24(5):723-738.

44. Šefer D., Marković R, Nedeljković-Trailović J, Petrujkić B., Radulović S., Grdović S: The application of biotechnology in animal nutrition. Vet. glasnik 2015, 69 (1-2): 127 - 137.

45. EFSA. Review of mycotoxin-detoxifying agents used as feed additives: mode of action, efficacy and feed/food safety. Sci. Report submitted to EFSA 2009, 1-192. http:// onlinelibrary.wiley.com/doi/10.2903/sp.efsa.2009.EN-22/epdf

46. Nesic V, Resanovic R, Marinkovic D, Nesic K, Lazarevic M, Nesic S, Aleksic-Kovacevic S: Efficacy of T-2 toxin detoxifying agent in broiler chickens. Acta Veterinaria-Beograd 2012, $62(2-3): 171-182$.

47. Nedeljkovic Trailovic J, Stefanovic S, Trailovic S: In vitro investigation tree different adsorbents against ochratoxin A in brilers. Brit Poult Sci, 2013, 54(4):515-23.

48. Nedeljkovic Trailovic J, Trailovic S, Resanovic R, Milicevic D, Jovanovic M, Vasiljevic M: Comparative Investigation of the Efficacy of Three Different Adsorbents against OTAInduced Toxicity in Broiler Chickens. Toxins 2015, 7(4), 1174-1191.

49. Nesic K, Resanovic R, Nesic V, Sinovec Z: Efficacy of mineral and organic adsorbent in alleviating harmful effects of zearalenone on pigs performance and health. Acta VeterinariaBeograd 2008, 58(2-3):211-219.

50. Tilley JEN, Grimes JL, Koci MD, Ali RA, Stark CR, Nighot PK, Middleton TF, Fahrenholz A C: Efficacy of feed additives to reduce the effect of naturally occurring mycotoxins fed to turkey hen poults reared to 6weeks of age. Poult Sci 2017, 96(12): 4236-4244. 


\title{
MIKOTOKSINI -KLIMATSKI UTICAJ I PREVENCIJA NA OSNOVU PROGNOZE
}

\author{
NEŠIĆ Ksenija
}

Iako su mikotoksini prisutni širom sveta i predstavljaju globalnu pretnju javnom zdravlju, njihova prevalenca i količine u hrani i hrani za životinje variraju usled geografskih i klimatskih razlika. Takođe, u skladu sa klimatskim promenama, predviđenim rastom spoljašnjih temperatura i modifikovanjem obrazaca padavina, uobičajena mikotoksikološka šema se transformiše, a neočekivane ekstremne situacije češće su u praksi. Takvi vremenski uslovi doprinose eskalaciji plesni i povećanju koncentracije mikotoksina u biljnim kulturama. Posledično, rizik po zdravlje ljudi i životinja raste, a strategije za ublažavanje negativnih efekata postaju složenije. Sve ovo takođe uzrokuje i značajne ekonomske gubitke. Stoga se ukazala potreba i zadatak za predviđanjem mikotoksikoloških prilika nedavno je stavljen pred multidisciplinarnu naučnu zajednicu, dok je ciljana prevencija postala značajna. Ovaj rad predstavlja pregled najnovijih dostignuća u ovoj oblasti, a pripremljen je s namerom da se sumiraju i integrišu raspoloživi podaci. 